\section{Astronomy in the United States}

A PANEL to estimate the probable need for major new facilities in astronomy in the United States during the next. 5-10 years has been set up by the National Academy of Sciences. Dr. Albert E. Whitford, director of Lick Observatory, Mount Hamilton, California, is chairman of the panel. Chairman of the Committee on Government Pelations is Dr. George B. Kistiakowsky, professor of chemistry, Harvard University, who was special assistant on scicnco and technology to President Eisenhower.

The, panel will concern jtself mainly with solar and galactic astronomy, optical and radio astronomy, groundbased and space astronomy, independent research observatories and those connected with universities. Tho astronomer members of the panel will also discuss the needs of astronomy with respect to manpowor and the use of new devices such as high-speed computers for the automation of telescopes and the processing of data, electronic-image tubes as substitutes for photographic plates, and radio-astronomy recoivers. Othor membors of the panol aro: Prof. R. N. Bracewell, Stanford University; Prof. Frederick T. Haddock, jun., University of Michigan; Dr. Frank D. Drake, National Radio Astronomy Observatory, (Kroen Bank, West Virginia; Dr. William Liller, Harvard College Observatory; Dr. W. W. Morgan, Yerkes Observatory, University of Chicago; Mr. Bruce H. Rule, California Institute of Technology; and Dr. Allan R. Sandago, Mount Wilson and Palomar Observatories.

The Institute for Medical Research, Federation of Malaya

'THE annual report of the Institute for Medical Rosearch. Fedoration of Malaya, for 1960, which includes a report from the United States Army Medical Research Unit, (Malaya) and statistical appendixes, as woll as a list of publications and reports, includes also a report on the oighth and final year of continuous filariasis investigations (Pp. vi+184. Kuala Lumpur: Institute for Medical Research, 1962. 2.50 Malayan dollars). This report unvisages a co-ordinated campaign of control by mass troatment with diethylearbamazine, starting in 1961, of all per'sons living in endemic areas, estimated at 5 per cont of the population. Research on Salmonella typhi phage types in Malaya continued, but routine biochemical estimations occupied most of the time of the staff of the Division of Biochemistry. The Division of Entomology finished its intensive collection of culicine mosquitoes, and in wall tests with Aedes aegypti a new formulation of benzene hexachloride containing a resin gave similar results to the normal wettable powder formulation. An invostigation into monkey malaria in the country was commenced, and a notable advance was mado in cooperation by Government agencies to improve nutrition in rural areas. A valuable development was the opening of a plant for the production of tuna fish meal by a cornmercial firm in Penang. Further ovidence was obtained that leptospirosis is a common infection in humans in Malaya.

\section{Salary Re-scaling for Colleges of Advanced Technology}

IN replying for the Govornment in the House of Commons on January 23, the Parliamentary Secretary to the Ministry of Education, Mr. C. Chataway, said it was intended, as one consequence of the transfer of the colleges of advanced technology to direct grant, that salaries of the stiaff in the Colleges should bo related to those of university staffs. By the end of summer 1962 , broad agreement had been reached between the Ministry and the national teachers' bodies concerned, on the main outlines of the negotiating procedure to be followed for this transition from the Burnham system to one more closely relatod to the university system. Tho Government, however, was at this time also considering the position with regard to university salary negotiations, and eventually concluded the review of university salaries was most appropriately referred to the National Incomes Commission and that colloge of advanced technology salaries should be simultaneously referred to the Commission. The Commission had not yet settled the procedure for the submission of evidence, but when it had done so the various bodies concorned would be fully informed. When it was decided to authorize an immediate overall increase of 10 per cent in university salaries it was also decided, in viow of the very substantial increase which college of advanced technology staffs had received as a result of the last Burnham settlement in January 1962, that any adjustments in their salaries should be limited to the more senior gradcs. 'The precise adjustments will be a matter for discussion with the teachers associations and the reprosentatives of tho chairmen and principals of the colleges as soon as it is known what increases are to be approved for the various grades of university staff. Mr. Chataway added that he fully shared the view that the colleges must be recognized as equivalent. in status to universities but that decision on that must await the Robbins report.

\section{Films on the Peaceful Uses of Atomic Energy}

As part of its continuing programme to make information available in its Member States, the International Atomic Energy Agency has established a film library and has recently publishod a catalogue of the 167 films that are now available for loan (Film Catalogue No. 1: Films on the Peaceful Uses of Atomic Energy available through the International Atomic Energy Agency. Pp. v+51. Vienna: International Atomic Energy Ageney, 1962). In the catalogue, films are listed under subject headings such as geology, safety, instrumentation, space, physics, radioisotopes, reactors, waste disposal. Each film is briefly described in a fow sentences of text. Indicated in tabular form are country of origin, date of production, length, languages available and whether the film is in colour or black-and-white. Although most of the films at present available are in English, about fifteen are available in French, sevon in Russian, four in German and one each in Spanish, Italian and Japanese. Several films aro available in more than ono language. Films are loaned to organizations in the Agency's 78 Member Nations for only the cost of return shipment. Copies of the catalogue are available from the Film Library, the International Atomic Energy Agency, Kärntnerring 11, Vienna I.

\section{Bibliography on Direction Finding and Related lono- spheric Propagation}

Following a conference held at the University of California at Los Angeles in June 1960, at which the aspects of long-range high-frequency radio propagation that affect radio-location and diroction-finding, and the related problems of measurement and analysis, were discussed, it was decided to launch a Bibliography on Direction Finding and Related Ionospheric Propagation Topics (Edited by Olaf D. Rommler. National Bureau of Standards Technical Note 127. Pp. 115. U.S. Government Printing Office, Washington 25, T.C. 1962.60 cents). A group of the papers presented at the conference was published in Radio Propagation, Section D of the Journal of Research of the National Bureau of Standards, May-June issue, 1961. This bibliography, though not exhaustive, includes more than 850 titles on direction finding and related topics including instrumental details, observations and data analysis, and theories of propagation. In connexion with the conference, the Numerical Analysis Research Straff of the University of California at Los Angeles prepared a bibliography of works on the conference subject published during 1955-59. This has since been edited and extended to include references to individual papers resulting in the presont publication published during 1955-mid-1961. In addition, references 